\title{
Optimum Utilization of Locally Available Waste Materials in Enhancing the Properties of Concrete
}

\author{
PL. Meyyappan
}

\begin{abstract}
The current challenges faced by the civil professionals are unbearable high cost of construction materials, green house effects and disposal of waste materials. All these problems are raised due to the limited supply of natural materials, more construction demand, and enormous generation of waste materials from various sources of occupations etc. The superlative solution for all the problems is to utilize the possible maximum extend of waste materials to the manufacturing of construction materials without compromising its properties. In regarding that, an attempt is made to study the possible way of utilizing the locally available waste products such as sugar cane bagasse, wild green grass and rice husk in to the concrete. All these waste products are dried and burnt into fine ashes. These ashes are added in to the concrete with various proportions such as $0 \%, 5 \%, 10 \%, 15 \%$, $20 \%, 25 \%$ and $30 \%$ for examining the strength and durability properties of $M 20$ grade concrete. The test results reveal that, the waste products can be effectively in to the concrete and the optimum proportion found to be around $15 \%$ to $20 \%$.
\end{abstract}

Keywords : Waste Materials, Sugar cane bagasse, Rice husk ash, Green grass ash, Concrete

\section{INTRODUCTION}

In one side, the today's scenario related to construction sector instructing that construction materials are costing very high and scarcely available. Even the governments are taking severe steps in procuring the natural available construction materials. On the other side the green house effect issues. In regarding that, severe warnings were given as alarm to reduce the usage of cement materials on construction related activities. Generally the agriculture, house hold, industrial and non-industrial activities generate a lot of waste materials either directly or in-directly during their life cycle. The disposal of waste materials generated remains more and more

as the population raises very drastically and this will also be a major environmental problem to be addressed. In order to give a balanced solution for the abovementioned issues, it will be most advantageous, if waste materials can effectively utilized as some replacement for the construction materials. By this way, many problems were addressed such as protecting the natural resources, reduction of global warming, effectual handling and disposal of wastes, minimizing the cost of the construction materials etc. Hence an attempt is made to investigate the effective utilization of locally available waste product/materials such as sugar cane bagasse, wild green grass and rice husk on the M20 grade concrete to examine its enhancement in the properties such as

Revised Manuscript Received on December 30, 2019.

* Correspondence Author

PL. Meyyappan*, Civil department, Kalasalingam Academy of Research and Education, Krishnankoil, India. Email: meyyappan@klu.ac.in compressive strength and water absorption.

\section{MATERIAL USED}

The following materials were used in this investigation:

A. Cement:43 grade Ordinary Portland Cement (OPC) confirming to the standards of IS: 8112 code.

B. Fine Aggregate:River sand passing through $2.36 \mathrm{~mm}$ IS sieve having a specific gravity of 2.61 and confirming to grading zone II as per IS:383 code.

C. Coarse Aggregate : Crushed granite coarse aggregates of $20 \mathrm{~mm}$ maximum size having a specific gravity of 2.69 .

D. Water: Potable drinking water

E. Sugarcane bagasse ash: It is the fiber left over the juice has been squeezed out of sugarcane stalks which are collected from the juice shop nearby krishnankoil. It will be dried in the natural atmosphere and burnt into ashes.

F. Grass ash: In one of the agriculture land, nearby krishnankoil, the unwanted wild grasses are collected, made dry and burnt to ashes.

G. Rice husk ash: Rice husk has been collected from the srivilliputtur rice mill and burnt in to ashes.

\section{EXPERIMENTAL INVESTIGATION}

For this experimental investigation, the mix ratio of M20 grade of concrete was arrived as the standards of IS 10262:2009. The ratio of design mix proportion obtained was 1 (C) : 1.18 (FA) : 2.52 (CA) with a W/c ratio of 0.45 . In order to achieve the above mentioned objectives of the study, the different kinds of ashes namely sugar cane ash, grass ash and rice husk ash were mixed in to the concrete in the proportions of $0 \%, 5 \%, 10 \%, 15 \%, 20 \%, 25 \%$ and $30 \%$ to examine the enhancement rate on the strength and water absorption properties of concrete. Totally 57 cube specimens of dimension $150 \mathrm{~mm}$ x $150 \mathrm{~mm} \times 150 \mathrm{~mm}$ each for the compression test and water absorption test are planned for this experimental investigation as descriptively mentioned in Table 1 against various ash proportions for 28 days age of curing. After mixing the concrete ingredients such as cement, fine aggregate and coarse aggregates thoroughly in the dry state of mix, the calculated amount of water is used to prepare the wet mix for the preparation of control specimen.

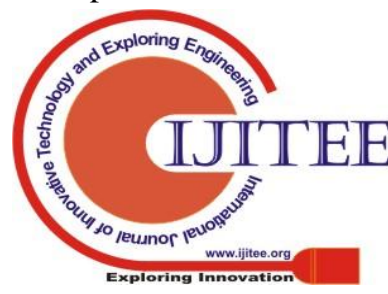




\section{Optimum Utilization of Locally Available Waste Materials in Enhancing the Properties of Concrete}

For preparing ash mixed concrete, calculated amount of proportion of ash is uniformly mixed with the regular concrete ingredients in the dry state before water is mixed.

Table- I: Name Test Specimen details

\begin{tabular}{|c|c|c|c|}
\hline Description & Proportions & $\begin{array}{l}\text { Compressive } \\
\text { Strength test }\end{array}$ & $\begin{array}{c}\text { Water } \\
\text { Absorption } \\
\text { test }\end{array}$ \\
\hline Control specimen & $0 \%$ ash & 3 & 3 \\
\hline Sugar cane bagasse ash mix & \multirow{3}{*}{$\begin{array}{c}5 \%, 10 \%, \\
15 \%, 20 \%, \\
25 \% \text { and } \\
30 \%\end{array}$} & 18 & 18 \\
\hline Grass ash mix & & 18 & 18 \\
\hline Rice husk ash mix & & 18 & 18 \\
\hline Total & 7 & 57 & 57 \\
\hline
\end{tabular}

The prepared concrete is filled in the respective cube moulds after proper hand compaction. After demould in 24 hours, the specimens were allowed for 28 days curing in water. The compressive strength of the cube specimen is found out from compression testing machine and the loads were applied until the specimen fail. The cubes were taken after 28 days curing and measured the initial weight as W1. Then it was allowed for a period of 24 hours in hot air oven at $200^{\circ} \mathrm{C}$. Then the weight is taken as W2. The percentage of weight differences between those weights is taken as water absorption rate of the specimen.

\section{RESULT AND DISCUSSIONS}

Table II - IV shows the experimental test results of compressive strength and water absorption for sugarcane ash mix (SA), grass ash mix (GA) and rice husk ash mix (RA) for 28 days age of curing. For a control specimen (without adding any ash), the compressive strength obtained is 20.3 $\mathrm{N} / \mathrm{mm}^{2}$ and water absorption is $6.67 \%$. By adding $5 \%$ sugar cane ash (SA), the strength is slightly increased by $3 \%$ and water absorption is moderately decline by $10 \%$. This kind of trend is continuing for the addition of $10 \%$ and $15 \%$ addition of SA and the strength obtained is $22.4 \mathrm{~N} / \mathrm{mm}^{2}$ (by increasing $10 \%$ ) and $24.2 \mathrm{~N} / \mathrm{mm}^{2}$ (by increasing $17 \%$ ) respectively and corresponding water absorption rate is reduced to $4.41 \%$ (by decreasing $33 \%$ ) and $3.64 \%$ (by decreasing 45\%). When SA addition is increased beyond $15 \%$, (i.e $20 \%$ SA) the results are not favourable. The strength is decreasing by $5 \%$ and water absorption rate is increased by $15 \%$ when compared with $15 \%$ addition of SA but any how, when comparable with control specimen the strength and water absorption is somewhat in a better manner as indicated in Figure 1. When the same SA is added up to $30 \%$, the strength is drastically reduced to $20 \%$ and water absorption rate is higher by $30 \%$. For addition of 5\% GA instead of SA, the strength attained is almost same and water absorption is very megerly reduced by $5.4 \%$ for $5 \%$ addition as mentioned in Table 2 . As seen in the case of SA, the addition of GA up to $15 \%$, also having the same trend in increasing in the strength and reduction in the water absorption criterion. There will be a increasing in strength by $7 \%$ and $11 \%$ and reduction in water absorption by $15 \%$ and $29 \%$ for the addition of GA $10 \%$ and $15 \%$ respectively. But the performance is in the dawdling desiring trend. As expected like in SA, after reached an optimum desired percentage of $15 \% \mathrm{GA}$, the strength is in the diminishing manner and water absorption in the amplifing manner.

Table- II: Test results for sugarcane ash mix

\begin{tabular}{|c|c|c|}
\hline $\begin{array}{c}\text { \% of } \\
\text { Sugarcane } \\
\text { Ash added }\end{array}$ & $\begin{array}{c}\text { Compressive } \\
\text { Strength } \\
\left(\mathbf{N} / \mathbf{m m}^{\mathbf{2}}\right)\end{array}$ & $\begin{array}{c}\text { Water } \\
\text { Absorption } \\
(\boldsymbol{\%})\end{array}$ \\
\hline 0 & 20.3 & 6.67 \\
\hline 5 & 20.9 & 6.06 \\
\hline 10 & 22.4 & 4.41 \\
\hline 15 & 24.2 & 3.64 \\
\hline 20 & 23.1 & 4.28 \\
\hline 25 & 19.7 & 6.89 \\
\hline 30 & 16.4 & 9.32 \\
\hline
\end{tabular}

Table- III: Test results for grass ash mix

\begin{tabular}{|c|c|c|}
\hline $\begin{array}{l}\text { \% of } \\
\text { Ash } \\
\text { added }\end{array}$ & $\begin{array}{c}\text { Compressive } \\
\text { Strength } \\
\left(\mathbf{N} / \mathbf{m m}^{2}\right)\end{array}$ & $\begin{array}{c}\text { Water } \\
\text { Absorption } \\
(\%)\end{array}$ \\
\hline 0 & 20.3 & 6.67 \\
\hline 5 & 20.5 & 6.32 \\
\hline 10 & 21.7 & 5.65 \\
\hline 15 & 22.8 & 4.78 \\
\hline 20 & 21.1 & 5.87 \\
\hline 25 & 18.4 & 7.12 \\
\hline 30 & 16.1 & 9.48 \\
\hline
\end{tabular}

Table- IV: Test results for rice husk ash mix

\begin{tabular}{|c|c|c|}
\hline $\begin{array}{l}\text { \% of Rice } \\
\text { Husk Ash } \\
\text { added }\end{array}$ & $\begin{array}{c}\text { Compressive } \\
\text { Strength } \\
\left(\mathbf{N} / \mathbf{m m}^{2}\right)\end{array}$ & $\begin{array}{c}\text { Water } \\
\text { Absorption } \\
(\%)\end{array}$ \\
\hline 0 & 20.3 & 6.67 \\
\hline 5 & 21.8 & 5.43 \\
\hline 10 & 23.3 & 4.29 \\
\hline 15 & 25.8 & 3.11 \\
\hline 20 & 24.1 & 3.54 \\
\hline 25 & 21.9 & 5.26 \\
\hline 30 & 19.1 & \\
\hline
\end{tabular}


For a maximum addition of $30 \% \mathrm{GA}$, the strength is 16.3 $\mathrm{N} / \mathrm{mm}^{2}$ (reduction by $21 \%$ ) and water absorption is $9.48 \%$ (increased by around $30 \%$ ) as clearly defined in Figure 1 and 2. For the addition of RA, the strength is increased by $7 \%$ and water absorption is decreased by $19 \%$ which is higher SA and GA in $5 \%$ addition as mentioned in Table 3.The strength is continued to be increased higher as $22 \%$ for the addition upto $15 \%$. The water absorption rate is seemed to be a prolonged diminution of $53 \%$. As resembling like SA and GA, the RA is also performing in the same fashion of undesired results for the addition of ash composition beyond $15 \%$. The strength is slightly reduced to $5 \%$ and water absorption is moderately enhanced to $11 \%$ for the maximum addition of $30 \%$ RA. As results distinctly indicating that, among the three kinds of waste material ashes, the performance is better for RA than $\mathrm{SA}$ and then GA. For all the kind of ashes, the optimum percentage of addition is at around $15 \%$ to $20 \%$. Upto that percentage of addition, the ashes are likely to be filling the micro pores of the concrete along with the hydrated products and thereby strength is in the augmented manner. Beyond the optimum percentage, further addition of ash, leads to undesired results.

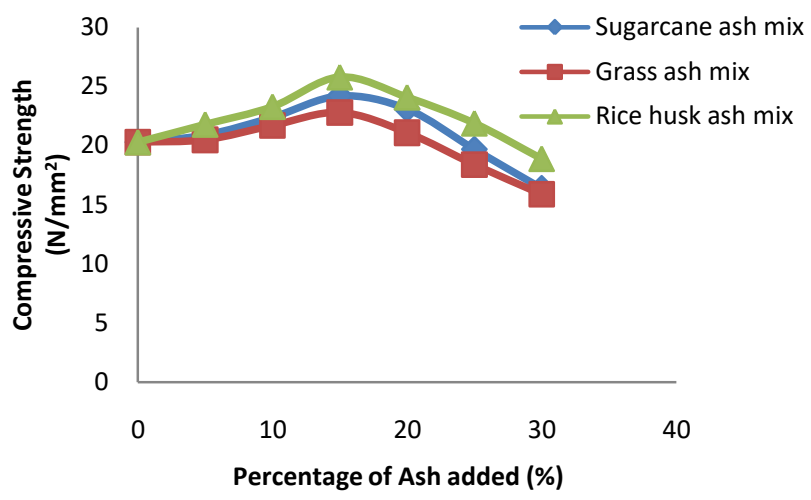

Fig. 1.Compressive strength Vs Addition of ash percentage

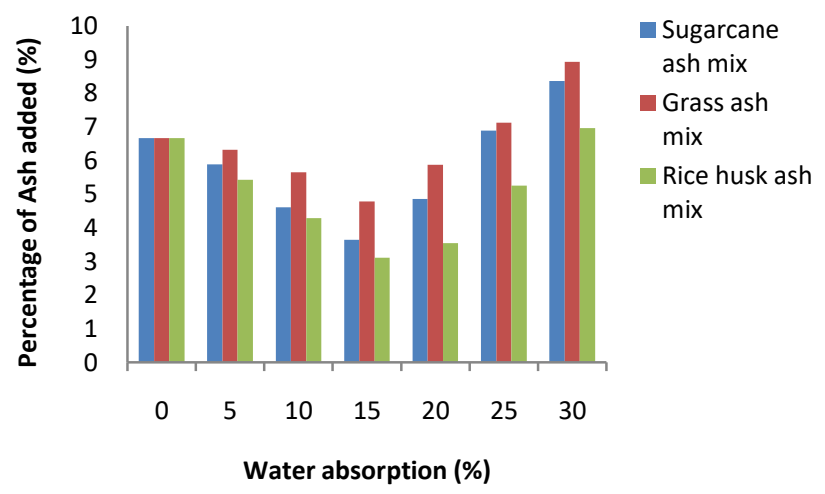

Fig. 2. Water absorption Vs Addition of ash percentage

\section{CONCLUSIONS}

1) From the experimental investigation, it is clearly mentioning that the presence of waste materials ashes in concrete is enhancing the properties of concrete in terms of strength and durability aspects irrespective of the rate of performance.
2) As seen that, the performance of rice husk ash is much better than other two ashes, since the strength is amplified to $22 \%$ and water absorption rate is decline to $54 \%$. This is happened by the presence of fine particles of ash filling the micro pores structure of the concrete.

3) The optimum addition of ash in the concrete as arrived as $15 \%$ to $20 \%$.

4) This study gives an idea for effective handling and usage of locally available wastes materials in improving the significant performance of building materials and thereby it is possible to initiate the utilization of green building materials.

\section{REFERENCES}

1. Bosela, P., Delatte, N., Obrati, R., Patel, A., 2008. Fresh and $\mathrm{G}=$ hardened properties of paving concrete with steel slag aggregates. In: Proceedings, 9th International Conference on Concrete Pavements, San Francisco, California, 2008

2. PL. Meyyappan, K.Kumaran, M.Gopalakrishnan and E. Harikrishnan (2018), "Effect of glass fibers, flyash and quarry ash on Strength and Durability Aspects of Concrete - An Experimental Study", IOP Conference Series: Material Science and Engineering, doi:10.1088/1757-899X/396/1/012001.

3. Kaur, M., \& Kaur, M. (2012). A Review on Utilization of Coconut Shell as Coarse Aggregates in Mass Concrete. International Journal of Applied Engineering Research, 7(11), 7-9.

4. Olanipekun, E. a., Olusola, K. O., \& Ata, O. (2006). A comparative study of concrete properties using coconut shell and palm kernel shell as coarse aggregates. Building and Environment, 41(3), 297-301. doi:10.1016/j.buildenv.2005.01.029

5. A. Halicka, P. Ogrodnik, and B. Zegardlo, "Using ceramic sanitary ware waste as concrete aggregate," Constr. Build.Mater., vol. 48, no. May, pp. 295-305, 2013.

6. J Ajnavi S., Bioconversion of Cellulosic Agricultural Wastes. Masters Technol Diss Dep Biotechnol Environ Sci ThaparUniv. 2008; (60601011).

7. PL. Meyyappan, K.Kumaran, M.Gopalakrishnan and E. Harikrishnan (2018), "Experimental Investigation on the Effect of Silica fume and Pumice stone in Developing Light Weight Concrete", IOP Conference Series: Material Science and Engineering, doi:10.1088/1757-899X/561/1/012064.

8. PL. Meyyappan, P. Amuthakannan, R. Sutharsan and M. Ahamed Azik Ali (2019), "Utilization of M-Sand \& Basalt Fiber in Concrete: An Experimental Study on Strength and Durability Properties", IOP Conference Series: Material Science and Engineering, doi:10.1088/1757-899X/561/1/012035.

\section{AUTHORS PROFILE}

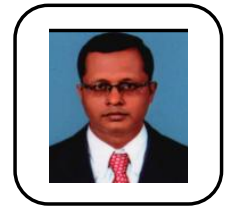

Dr. PL. Meyyappan has completed his graduation and post-graduation from Bharathiyar University and Karunya University respectively. He completed his $\mathrm{PhD}$ from Kalasalingam University. He has 13 years of teaching experience. He has completed 2 sponsored research projects from TNSCST and published more than 25 papers in peer reviewed journals and conferences. He is a life member in ISTE, IEI, IGS, ISET, ISRS. He is serving as Editorial Board Member and Reviewer in various reputed Journals. 